\title{
Moringa oleifera Lam flour biscuits.: a possibility of child supplement
}

\author{
Biscoitos de farinha de Moringa oleifera Lam.: uma possibilidade de suplemento infantil \\ Galletas de harina Moringa oleifera Lam.: una posibilidad de suplemento infantil
}

Received: 02/09/2022 | Reviewed: 02/15/2022 | Accept: 02/18/2022 | Published: 02/26/2022

\author{
Maria Tatiana Pinto Coelho \\ ORCID: https://orcid.org/0000-0002-9697-615X \\ Universidade Católica Dom Bosco, Brasil \\ E-mail: tatianacoelho1@gmail.com \\ Cristiane Vasconcelos Figueiredo \\ ORCID: https://orcid.org/0000-0003-4565-4203 \\ Universidade Católica Dom Bosco, Brasil \\ E-mail:cristianefigueiredo399@gmail.com \\ Adriana da Silva Flores Fabrão Moraes \\ ORCID: https://orcid.org/0000-0001-5437-6407 \\ Universidade Católica Dom Bosco, Brasil \\ E-mail:rf5748@ucdb.br \\ Lilliam May Grespan Estodutto da Silva \\ ORCID: https://orcid.org/0000-0001-7264-2617 \\ Universidade Católica Dom Bosco, Brasil \\ E-mail: lmaygrespan@gmail.com
}

\begin{abstract}
The Moringa oleifera (Mo) is a perennial species, of the family Moringaceae, originating in the Himalayas. It is full of benefits to human health, as it helps in the prevention and fight of various diseases, including iron deficiency anemia in children. Interest in this plant and its benefits has increased, many scientists study its nutritional and medicinal properties. Based on these statements, this work aimed to produce Mo flour (leaf powder) and biscuits with the partial replacement of conventional flours, as well as the evaluation of chemical compositions, sensory and acceptability analyses, as well as the possible use of biscuit as a food supplement for children. The study was divided into five stages: flour preparation; preparation of the biscuit; bromatological analysis; sensory analysis and acceptability test and statistical analysis. The values found are arranged and presented in tables and graphs detailing in detail for a better evaluation, among which vitamin $\mathrm{C}$ and iron stand out. The biscuits showed high acceptability, so the Mo flour and biscuits can be considered good sources of proteins, carbohydrates, lipids, fibers, vitamin C, and iron, an alternative supplement in food preparations.
\end{abstract}

Keywords: Nutritional properties; Food supplement; Iron deficiency anemia.

\section{Resumo}

A Moringa oleifera (Mo) é uma espécie perene, da família Moringaceae, originária do Himalaia. É farta em benefícios à saúde humana, pois ajuda na prevenção e no combate de várias doenças, entre elas a anemia ferropriva em crianças. $\mathrm{O}$ interesse por esta planta e pelos seus benefícios tem aumentado, muitos cientistas estudam suas propriedades nutricionais e medicinais. A partir destas afirmações este trabalho teve como objetivo a produção da farinha da Mo (pó da folha) e de biscoitos com a substituição parcial das farinhas convencionais, assim como a avaliação das composições químicas, análises sensorial e de aceitabilidade, bem como a possível utilização do biscoito como um suplemento alimentar para crianças. $\mathrm{O}$ estudo foi dividido em cinco etapas: elaboração da farinha; elaboração do biscoito; análise bromatológica; análise sensorial e teste de aceitabilidade e análise estatística. Os valores encontrados estão dispostos e apresentados em formas de tabelas e gráficos detalhando minunciosamente, e para melhor avaliação dentre eles se destacam a vitamina $\mathrm{C}$ e o ferro. Os biscoitos apresentaram uma aceitabilidade elevada, assim a farinha e o biscoito da Mo podem ser considerados boas fontes de proteínas, carboidratos, lipídeos, fibras, vitamina $\mathrm{C}$ e ferro, uma alternativa de suplemento em preparações alimentícias.

Palavras-chave: Propriedades nutricionais; Suplemento alimentar; Anemia ferropriva.

\section{Resumen}

Moringa oleifera (Mo) es una especie perenne, de la familia Moringaceae, originaria del Himalaya. Está lleno de beneficios para la salud humana, ya que ayuda en la prevención y lucha de diversas enfermedades, incluida la anemia por deficiencia de hierro en los niños. El interés en esta planta y sus beneficios ha aumentado, muchos científicos estudian sus propiedades nutricionales y medicinales. A partir de estas afirmaciones, este trabajo tuvo como objetivo producir harina Mo (hoja en polvo) y galletas con el reemplazo parcial de harinas convencionales, así como la evaluación de composiciones químicas, análisis sensoriales y de aceptabilidad, así como el posible uso de galleta como complemento alimenticio para niños. El estudio se dividió en cinco etapas: preparación de harina; preparación de la galleta; análisis bromatológico; análisis sensorial y prueba de aceptabilidad y análisis estadístico. Los valores 
encontrados están ordenados y presentados en tablas y gráficos detallando en detalle para uns mejor evaluación, entre los que destacan la vitamina $\mathrm{C}$ y el hierro. Las galletas mostraron una alta aceptabilidad, por lo que la harina de Mo y las galletas pueden considerarse buenas fuentes de proteínas, carbohidratos, lípidos, fibras, vitamina $\mathrm{C}$ y hierro, un complemento alternativo en las preparaciones alimenticias.

Palabras clave: Propiedades nutricionales; Complemento alimenticio; Anemia ferropénica.

\section{Introduction}

Brazil is a country with vast biodiversity with a flora rich in nutrients and minerals. Non-conventional vegetables are a food alternative and an option of agricultural activity, besides being plants with excellent nutritional value, easy to grow and low cost (Rocha, et al, 2008) among them is the Moringa oleifera, (Mo), a perennial and arboreal vegetable, and its cultivation is due to the high capacity of adaptation to climatic conditions and arid soils, combined with the possibility of using leaves, green fruits, flowers, and toasted seeds, with representative amounts of nutrients (Gasqui, et al, 2015).

Moringa oleifera has nutritional properties that complement daily feeding. The content in proteins, vitamins, and minerals is significant and is considered one of the best perennial vegetables. The leaves have a pleasant flavor, can be consumed cooked in soups, stews, and varied dishes and have a slightly spicy flavor. The leaves and stems can be dried and used as a condiment, sprinkled on the food. The pod can be used green and fresh and tastes like peas when cooked. Seeds can be consumed cooked with salt, tastes like chickpeas, and can also be consumed with toast. Flowers can be used in salads and are considered an important source of nectar for bees (Helvio, 2007). The interest in studying this plant, its nutritional and medicinal properties, is due to the many beneficial discoveries of this plant. Because it is very abundant in nutritional properties, both in macronutrients and micronutrients, Moringa oleifera can be used as an ally in the treatment and prevention of iron deficiency anemia, because it has in its composition a high content of vitamin C and Iron, essential elements for the treatment of this pathology (Almeida, 2018).

Moringa's intake has a comprehensive nutritional and medicinal potential because it has highly digestible proteins, macronutrients, and as micronutrients calcium, iron, vitamin $\mathrm{C}$, is then considered food for people suffering from iron deficiency anemia (Gasqui, 2015). We highlight that malnourished children can benefit from the additional consumption of Moringa oleifera leaves in their diet. The high concentrations of iron, protein, copper, various vitamins, and essential amino acids present in Moringa leaves make it an ideal nutritional supplement.

According to the World Health Organization (2015), anemia is defined by low hemoglobin concentration in the human body due to the lack of one or more essential nutrients. It is a condition, where the content of hemoglobin, in this case, iron, is below the indicated amount, which causes low oxygen supply to the body, fatigue, fainting, shortness of breath, pallor, among others. Iron deficiency anemia still has a high incidence in developing countries, greatly affects the child's public, and is also correlated with inadequate nutrition. This is most often due to the precarious economic situation and the difficulty in accessing information and food education, which restricts the supply and demand of food, both in the variety and in the quantities necessary for the good physical development of children.

Most often, it is caused by the nutrient deficiency that occurs due to poor nutritional supply via food, which can occur already during pregnancy, in which the mother does not have an adequate diet, with necessary nutrients (specifically food sources of iron, vitamin $\mathrm{C}$ and calories) and sufficient to meet the needs, of her as a pregnant woman, and of the baby who is developing, which increases the chances of the newborn developing iron deficiency anemia (Silva, 2007).

This work aims to produce om flour and biscuits with the partial replacement of conventional flours by Moringa oleifera flour, as well as the evaluation of the physicochemical compositions of micronutrients, sensory and acceptability analyses, as well as the possible use of the biscuit as a food supplement for children. 


\section{Materials and Methods}

This work has an experimental design. The biscuits were prepared from the powder of the Moringa oleifera leaf, here called Moringa oleifera flour (Mo) in the Laboratory of Dietary Technique and the preparation of the powder and bromatological analyses occurred in the Laboratory of Food Technology, both of the Catholic University Don Bosco. The sensory analysis occurred in several places in Campo Grande-MS, with children aged 2 to 10 years, of both sexes. The study was divided into five stages: elaboration of Mo flour; preparation of biscuits; physicochemical characterization; sensory analysis and acceptability test; statistical analysis.

\subsection{Materials}

The leaves of Moringa oleifera were acquired on the private property of the city of Campo Grande-MS. The other ingredients used in the formulation of the biscuit, such as corn flour, wheat flour, sugar, butter, 100\% cocoa, baking soda, cinnamon powder, salt, and eggs were acquired in local shops in the city.

\subsection{Preparation of Moringa oleifera leaf powder}

After harvesting the leaves $(3 \mathrm{Kg})$ the branches were separated so that there was no interference at the time of preparation of om flour. Then the leaves were sanitized in running water and sanitized with a solution of sodium hypochlorite at 10 ppm, for 15 minutes and washed again in running water, then arranged in trays and placed in an oven for drying with forced air circulation at $40^{\circ} \mathrm{C}$ for 48 hours. After drying, they were crushed in a blender and sieved for homogenization, $445 \mathrm{~g}$ of dark green flour and strong smell, characteristic of mo leaf, the flour was stored in plastic packaging and stored for later use in bromatological analyses and biscuit manufacturing.

\subsection{Biscuit making}

For the preparation of the biscuits, preliminary tests were carried out with the Mo flour, to obtain the best formulation, through the evaluation of the texture of the dough and the general appearance of the biscuits.

The production of cookies took place in an artisanal way between April and May 2021, in the Laboratory of Dietetic Technique of the Catholic University of Don Bosco. All ingredients were weighed on a digital scale with a minimum accuracy of $1 \mathrm{~g}$, toledo brand, to obtain greater standardization between recipes, after they were mixed in a mixer of the domestic type, to obtain a homogeneous mass.

Modeling was carried out with biscuit molders so that everyone similarly presented themselves, with approximately 15 grams per unit. They were baked in a conventional preheated domestic oven, placed in baking sheets greased with butter at an average temperature of $180^{\circ} \mathrm{C}$ for 25 minutes, cooled until they reached room temperature, and stored individually in plastic bags so that bromatological and sensory analyses were subsequently performed. For the preparation of the biscuits, a standard recipe was used to develop various preparations, of which corn and wheat flours were gradually reduced, to add the Mo flour, until reaching the final quantity of $40 \mathrm{~g}$, which corresponds to $30 \%$ of Mo flour, in addition to the other ingredients added to the standard recipe so that it was possible to "equation" the flavor and texture (Table 1). 
Table 1 - List of standard recipe ingredients for the formulation of the Moringa oleifera biscuit.

\begin{tabular}{ll}
\hline Ingredients/Formula & Quantity \\
\hline Corn farinho & $500 \mathrm{~g}^{* *}$ \\
Wheat flour & $206 \mathrm{~g}$ \\
Refined sugar & $250 \mathrm{~g}$ \\
Eggs & $4 \mathrm{UN}^{*}$ \\
Butter & $125 \mathrm{~g}$ \\
Lemon zest & $1 / 2 \mathrm{UN}$ \\
Cinnamon powder & $1 \mathrm{~g}$ \\
Salt & $1 \mathrm{~g}$ \\
\hline
\end{tabular}

*g-grams; **UN- units. Source: Authors (2021).

To obtain the final result, four recipes were developed, discarding those that did not present good results regarding palatability, flavor, color, consistency, and texture. The preparation method used was the same for the four formulations. At the end of the experiment, only one cookie recipe (Table 2) was considered ideal for organoleptic characteristics considered ideal for consumption, in which $40 \%$ of Mo flour was used.

Table 2 - List of ingredients used for formulation 4 to obtain the biscuit, prepared with 40\% Moringa oleifera flour.

\begin{tabular}{ll}
\hline Makings & Quantity \\
\hline Corn flour & $350 \mathrm{~g}^{*}$ \\
Wheat flour & $306 \mathrm{~g}$ \\
Moringa flour & $40 \mathrm{~g}$ \\
Refined sugar & $300 \mathrm{~g}$ \\
Butter & $130 \mathrm{~g}$ \\
Cocoa $100 \%$ & $35 \mathrm{~g}$ \\
Baking soda & $10 \mathrm{~g}$ \\
Cinnamon powder & $1 \mathrm{~g}$ \\
Salt & $1 \mathrm{~g}$ \\
Eggs & 5 th UN* \\
Lemon zest & $1 / 2 \mathrm{UN}$ \\
Vanilla essence & $3 \mathrm{drops}$ \\
\hline
\end{tabular}

*g-grams; **UN- units. Source: Authors (2021).

\subsection{Analytical determinations in moringa leaf flour}

\subsubsection{Chemical composition}

The preparation of the sample to be analyzed was performed from the baked and crushed biscuits. Humidity was determined by the drying method. Because it is a gravimetric procedure, a process that isolates its component to its purest form, in which loss by desiccation occurs in an oven at $105^{\circ} \mathrm{C}$ until constant weight. The determination of the ashes was made from a gravimetric method also, in which the destruction of the organic matter present in the sample occurs (AOAC, 2016).

For protein, the amount of nitrogen was determined by the Micro-Kjeldahl method - neutralization titulometry, and the results were converted into crude protein with the application of conversion factor 6.25 (AOAC, 2000). Lipids were determined from the extraction method of the goldfish device, characterized by a continuous process, which obtains the lipid fraction present in the raw material to be used in the system. This process is carried out with solid samples and hot solvents, with the reflux of the solvent for oil extraction (Instituto Adolfo Lutz, 2008).

To determine the carbohydrate content, the Lane-Eynon method was performed using the Fehling reagent (AOAC, 2000). And, in the end, the determination of the fibers was performed by calculating the difference at $100 \%$. 
To determine vitamin C or L-ascorbic acid, the analysis was used, which is based on the oxidation of ascorbic acid by potassium iodate (Tavares, et al, 1999).

Iron determination was performed by the complexation of iron ions with iron thiocyanate, in the presence of iron forms a red coloration and determined its concentration by spectrophotometer (Instituto Adolfo Lutz, 2008).

All determinations were made in triplicate and then the means of the values were made. The results obtained were presented in percentage form and tables.

\subsection{Sensory analysis and acceptability of Moringa oleifera biscuit}

After the approval of the Research Ethics Committee (CEP) with the acceptance term of CAAE number 45226321.3.0000.5162, the sensory analyses were performed through the tasting of the biscuit prepared based on Moringa oleifera flour, in which the acceptability tests were performed with 25 children of both sexes, aged 2 to10 years, randomly selected. The test occurred after the signing of the consent form by the parents and the Consent form directed to children older than 6 years. The sensory and acceptability analysis was initiated on the 5th day after the preparation of the biscuits and, due to the availability of the evaluators, it was completed in 6 days, where it occurred in the Food Technology Laboratory of the Catholic University of Don Bosco Catholic - UCDB.

$1^{\circ}$ ) The evaluation of the flavor. We used the facial hedonic scale to verify the level of acceptance of the biscuits;

$2^{\circ}$ ) To evaluate the degree of acceptance of the product about color, flavor, and texture, also with the facial hedonic scale (Monteiro, 2005).

\subsection{Acceptability index}

The acceptability index (AI) of each preparation was analyzed according to the following expression: $\mathrm{A}(\%)=\mathrm{A} \times 100 /$ B, where A is the average score obtained by the product and B is the maximum score given to the product (Teixeira et al, 1987).

\subsection{Methodological support for research}

The data presented followed the protocols of teaching, research, and scientific methodology, as described by Estrela (2018).

\subsection{Statistical methods and data analysis}

For the statistical evaluation, in relation to categorical variables, the Q-square test was used to evaluate the influence of the profile of the acceptable of biscuits by the creations, being adopted as significance $\alpha=0.05$.

\section{Results and Discussion}

The analyses of the chemical and centesimal composition are presented separately for the Mo flour and the biscuit, table 3 shows the results obtained. The related assays are moisture, carbohydrate, protein, lipid, total fibers, in addition to iron and vitamin C. 
Table 3 - Centesimal composition of Moringa oleifera flour and biscuit.

\begin{tabular}{lll}
\hline Parameters & Moringa oleifera flour & Moringa oleifera biscuits \\
Humidity $\left(\mathrm{g} .100 \mathrm{~g}^{-1}\right)$ & $5.0 \pm 0.02^{\mathrm{b}}$ & $10.4 \pm 0.04^{\mathrm{a}}$ \\
Ashes $\left(\mathrm{g} .100 \mathrm{~g}^{-1}\right)$ & $9.4 \pm 0.32^{\mathrm{a}}$ & $1.5 \pm 0.22^{\mathrm{a}}$ \\
Protein $\left(\mathrm{g} .100 \mathrm{~g}^{-1}\right)$ & $25.7 \pm 0.21^{\mathrm{a}}$ & $5.6 \pm 0.16^{\mathrm{b}}$ \\
Lipid $\left(\mathrm{g} .100 \mathrm{~g}^{-1}\right)$ & $6.6 \pm 0.05^{\mathrm{b}}$ & $13.1 \pm 0.07^{\mathrm{b}}$ \\
Carbohydrate $\left(\mathrm{g} .100 \mathrm{~g}^{-1}\right)$ & $24.0 \pm 0.19^{\mathrm{a}}$ & $41.0 \pm 0.26^{\mathrm{b}}$ \\
Crude fiber $\left(\mathrm{g} .100 \mathrm{~g}^{-1}\right)$ & $19.4 \pm 0.25^{\mathrm{a}}$ & $27.8 \pm 0.14^{\mathrm{a}}$ \\
Vitamin C $\left(\mathrm{mg}^{\left.-100 \mathrm{~g}^{-1}\right)}\right.$ & $10.2 \pm 0.06^{\mathrm{b}}$ & $8.7 \pm 0.08^{\mathrm{a}}$ \\
Iron $\left(\mathrm{mg} .100 \mathrm{~g}^{-1}\right)$ & $3.5 \pm 0.16^{\mathrm{a}}$ & $2.4 \pm 0.13^{\mathrm{b}}$ \\
\hline
\end{tabular}

Means \pm standard deviation with different letters on the same line differed from each other by the Tukey test ( $<<0.05)$. Source: Authors $(2021)$.

When analyzing the results obtained for moisture, it can be observed that the values of Mo and biscuit flour were, respectively, $5.0 \%$ and $10.4 \%$. These values are considered appropriate with the standards established by the Brazilian Legislation. According to the National Health Surveillance Agency (2005), the moisture content for biscuits should not exceed $14 \%$, since it is characterized as a farinaceous product, so the results obtained for moisture of the biscuits are within the standard required by the legislation since they showed humidity below $14 \%$.

Even though the percentage of moisture of the flour was below, but within the established standards, the MS biscuit presented a higher value than the recommendation, but this difference did not become relevant, because this small difference may be related to the time of the manipulation process and the insertion of the ingredients of the formulation. Moisture is important in the storage of dry foods because higher levels than those established by Brazilian Legislation can provide microbial growth. The moisture content is related to its manufacturing process (Chisté, et al, 2006; Tibola, et al, 2010).

The study conducted by Passos et al, (2012), in which the Mo flour was also used was 9.9\%, a lower value than in the present study. Baptista et al. (2012), presents the study when devising cookies, in which he used Mo flour, found a moisture value of $10.8 \%$, a value that corroborated the one found in this study, which was $10.4 \%$. The values obtained from the ash content for Mo flour and biscuit were $9.4 \%$ and $1.5 \%$, respectively, it was observed in Teixeira's study, 2012, that he obtained a similar value for ashes from the Mo leaves, the value of $10.9 \%$.

Castro (2017), conducted a study in which he developed products based on Mo flour, which obtained results for the analysis of the ash content of $11.1 \%$, a result much higher than that found in the biscuit prepared here, as occurred in the study by Guiros, et al, 2019, where the ash content in the Mo leaves was 11.23\%. According to Almeida (2018), high ash contents (5 to $10 \%$ ) indicate the abundance of mineral elements in plants; he also reported that the high ash value is indicative of high levels of minerals such as calcium, phosphorus, iron, and magnesium. The maximum ash content allowed for Brazil (Brazil, 2005), for biscuits is no more than $3 \%$ and according to the Taco table (TACO, 2011), should not exceed the value of $1.5 \%$ for sweet biscuits of corn starch, thus it is understood that the biscuits prepared in this study were within the norms and recommendations, so because of their ash content, these may present a good nutritional value that refers to minerals.

The protein content found in the Mo leaf (flour) was $25.7 \%$, a value considered higher than that found in the study conducted by Gueiros, et al, (2019), which was $20.21 \%$, but lower than the results found in the studies conducted by Castro (2017) and Santos, et al, 2020, which obtained the results of $27.2 \%$ and $29.84 \%$, respectively. According to Modesti (2006), green leaves of vegetables with high protein content are indicated as food alternatives in the fight against malnutrition, considering that these leaves have low cost and high availability of nutrients. Therefore, there has been growing interest in research for new unconventional protein sources for application in the food industry.

However, the values obtained in this study were higher when compared to the protein contents of unconventional leaves: Silva, et al, 2001, obtained $17.92 \%$ for taioba; $18.46 \%$ for sawdust, and in carrot leaves obtained $15.2 \%$, while Modesti (2006) found in cassava leaves $14.55 \%$ protein. This high protein index presented by the present study demonstrates a choice of Mo 
flour for food enrichment. Macambira, et al, (2018), found $18.31 \%$ of proteins in the chemical composition of Moringa oleifera leaf bran and highlight that all parts of the moringa are rich in nutrients and compounds favorable to the proper functioning of the body. Mo leaves have a high percentage of protein, being higher than that presented in eggs, dairy products, besides containing more calcium than cow's milk. It also has a relatively high amount of vitamins A and C and significant amounts of minerals such as potassium, iron and magnesium. It is difficult to find a more complete food, its green leaves correspond to the group of foods that are used as an important food source in all parts of the world because they are rich sources of bioactive compounds, minerals and dietary fibers (Moreira, 2016).

The prepared biscuit presented in its protein analysis a result of 5.6\%, a value lower than that found in the study by Baptista et al, (2012), where the value of 6.05\% crude protein was obtained, however Santana et al. (2008), in their study with biscuit, the result of $0.37 \%$, a value much lower than that found in this study.

The lipid content of Mo flour was 6.6\%, lower than the value found by Gasqui, et al. (2015), which was $12.89 \%$ in Mo flour, but remained with a very close result with the analysis by Moyo et al. (2011), who presented a value of 6.5\% lipid. Regarding the biscuit, the value found for lipid was $13.14 \%$, higher than the study by Baptista et al. (2012), where the result was $8.81 \%$. It is understood that the variation in lipid content is by the ingredients used and the variation in the types of biscuits (sequilhos, cookies, light, among others). Lipids are components of great importance in human food because of their nutritional, functional, and organoleptic properties. They are sources of essential fatty acids and transporters of fat-soluble vitamins A, D, E, and K2. Therefore, it is important to consider the positive impact of the presence of this nutrient in the formulation of new products (Pinheiro et al., 2005).

The high carbohydrate content that Mo flour presented is indicative of a potentially energetic vegetable, Moura, et al, 2009, resulted in $24.0 \%$ in their study, which can be compared to those found by Silva et al. (2001) and Gasqui et al. (2015), with higher levels of $48.3 \%$ and $38.8 \%$. The biscuit presented high carbohydrate content (41.4\%) when compared to Mo flour (24.0\%), this is because the biscuit composition has other types of starch-rich flours such as wheat flour and corn flour. No studies were found that evaluated the carbohydrate content of the biscuits produced with Mo flour. Dietary fiber can influence several aspects of digestion, absorption, and metabolism, which makes them an adequate intestinal regulator, in addition to the prevention of diseases of the gastrointestinal tract, glycemic control, lipid, balance of the intestinal microbiota, immunity, and cardiovascular (Teixeira, 2012).

When compared with other food sources usually consumed, such as chard, watercress, broccoli, and lettuce with levels of approximately 3\% (TBCA, 2020), Moringa oleifera can be considered an important source of this nutrient. The daily amount of fiber ingested should be about 25 to 30g, but most people do not reach this amount with food (Siguemoto, 2013). The recommended value for the amount of fiber in children and adolescents is different for adults; American Health Foundation (AHF) presents those children over 2 years should add up to their age about $5 \mathrm{~g}$ to $10 \mathrm{~g}$ of fiber daily. That is, a 10-year-old child, for example, should consume between 15 and $20 \mathrm{~g}$ of fiber per day.

According to the legislation, through ordinance $\mathrm{n}^{\circ} .27$ of 1998 (Brazil, 2014), food to be rich in fiber must contain at least $6 \mathrm{~g}$ of fiber in $100 \mathrm{~g}$ of food, and to be a source of fibers must contain $3 \mathrm{~g}$ of fiber in $100 \mathrm{~g}$ of food. Fruet et al. (2014), reported that dietary fibers are researched for the beneficial effects recognized for collaborating with the sensory properties of food. The amount of fiber found in dry flour in Mo was 19.4\%, a value that was higher than the studies conducted by Teixeira (2012) which was $10.9 \%$, and that of Gasqui et al. (2015), which was $14.56 \%$ by Moyo et al. (2011), with a content of $11.4 \%$. As for the biscuit, it presented $27.8 \%$ of total fiber, when compared to the study by Baptista, et al, 2012, which was $1.41 \%$. It is understood that this difference may be due to the amount used of Mo flour in the preparation of the biscuit, which was superior to the study by Baptista, et al, 2012. Therefore, in this work, the crude fiber content found in both Mo and biscuit flour makes them can be 
considered high in fiber when compared with some foods, such as who leme al that has 3.0\%; carrot $6.0 \%$; cabbage $8.0 \%$; whole wheat meal 11.0\%; whole oats and rice bran $13.0 \%$ (TACO, 2011).

Regarding vitamin C, the present study identified in the flour content of $10.2 \mathrm{mg}$ a value lower than that found by Teixeira (2012) which was $17.3 \mathrm{mg}$, the amount of vitamin C present in the biscuit was $8.7 \mathrm{mg}$, which demonstrates that there was little loss of this mineral in the cooking process. Câmera et al. (2019), in their studies detailed the compositions of foods shows that it contains $164 \mathrm{mg}$ of vitamin C per 100g of fresh leaf, and Mensah, et al, 2012, verified in the powder of the leaf of Moringa oleifera the amount of vitamin C, the presence of $19.3 \mathrm{mg} / 100 \mathrm{~g}$. In the present, it was possible to observe that the dried leaves of Moringa oleifera values were also lower than that found by Mensah et al. (2012), and Siguemoto (2013).

RDC $N^{\circ} 269$ of September 2005 (Brazil, 2005), establishes the recommended daily intake (RDI) for nutrients, such as vitamin $\mathrm{C}$, the recommendation for children aged 4 to 10 years a daily dose of $45 \mathrm{mg}$ and for adults $60 \mathrm{mg}$. This amount can be acquired in the intake of $4.34 \mathrm{~g}$ of the fresh leaves of Moringa oleifera. Mo leaves can be incremented in various ways in human food, such as teas, juices, salads, seasonings, capsules, etc. Vitamin C, according to Câmara, et al, 2019, has hundreds of functions in the body, among them, acts as an antioxidant, cofactor for the biosynthesis of collagen, carnitine, peptide hormones, and neurotransmitters. The highest levels of vitamin $\mathrm{C}$ are found in vegetables and fruits such as orange, lemon, acerola, guava, and lemon. Most vegetables contain a significant amount of this vitamin, and Mo has gained prominence.

As for the iron content of Mo flour (dry leaf powder), a concentration of 3.5\% of this mineral was observed and, in the biscuit, it was $2.4 \%$. Many studies show that both iron and vitamins $\mathrm{C}$, present in Mo, will be in greater quantity when the leaves of this plant are harvested during the winter since this vitamin favors its absorption, but the bioavailability of iron will be higher when the leaves of this plant are submitted to a cooking treatment, that is, its use will be better, the more they are coccionadas (Moreira, 2016; Chamber, 2019).

Due to the large number of nutrients that Mo contains, it can be used to combat nutritional deficiencies, especially iron deficiency anemia (Romero et al., 2015). As stated in the study conducted by Shija et al. (2019), in which 206 children living in 4 African villages in Kisarawe district, Tanzania, were supplemented for 6 months with daily doses of 25g of Mo leaf powder, resulting in a reduction in the prevalence of anemia in communities by $53.6 \%$. The lack of studies demonstrating iron content and concentrations, both in flour and in biscuits made with flour, prevented a better discussion and comparison with the values obtained in the present study.

Silva et al. (2020), say that the amount of nutrients in food is affected by environmental conditions during their development in the field, by the conditions of harvest, drying, processing and storage. In addition, the identification of the physical-chemical characteristics and the quantification of these bioactive substances in the plant are of paramount importance, as they are of great interest to add nutritional quality and add value to the final product. Regarding the results of the sensory analysis of the biscuit, of the 25 children who evaluated the Moringa oleifera biscuit, $48 \%$ were male and $52 \%$ were female. The age group with the highest prevalence among participants was 5 to 10 years, which gives an average age of 6 years for both sexes. Figure 1 shows the acceptability of children regarding the color of the biscuit, where 52\% reported having "worshipped", $36 \%$ who "liked it"; for the items "hated", "did not like" and "indifferent" presented $12 \%$ of the answers (N=3). 
Figure 1 - Graphic of sensory analysis of biscuit of Moringa oleifera as to the in do not know color.

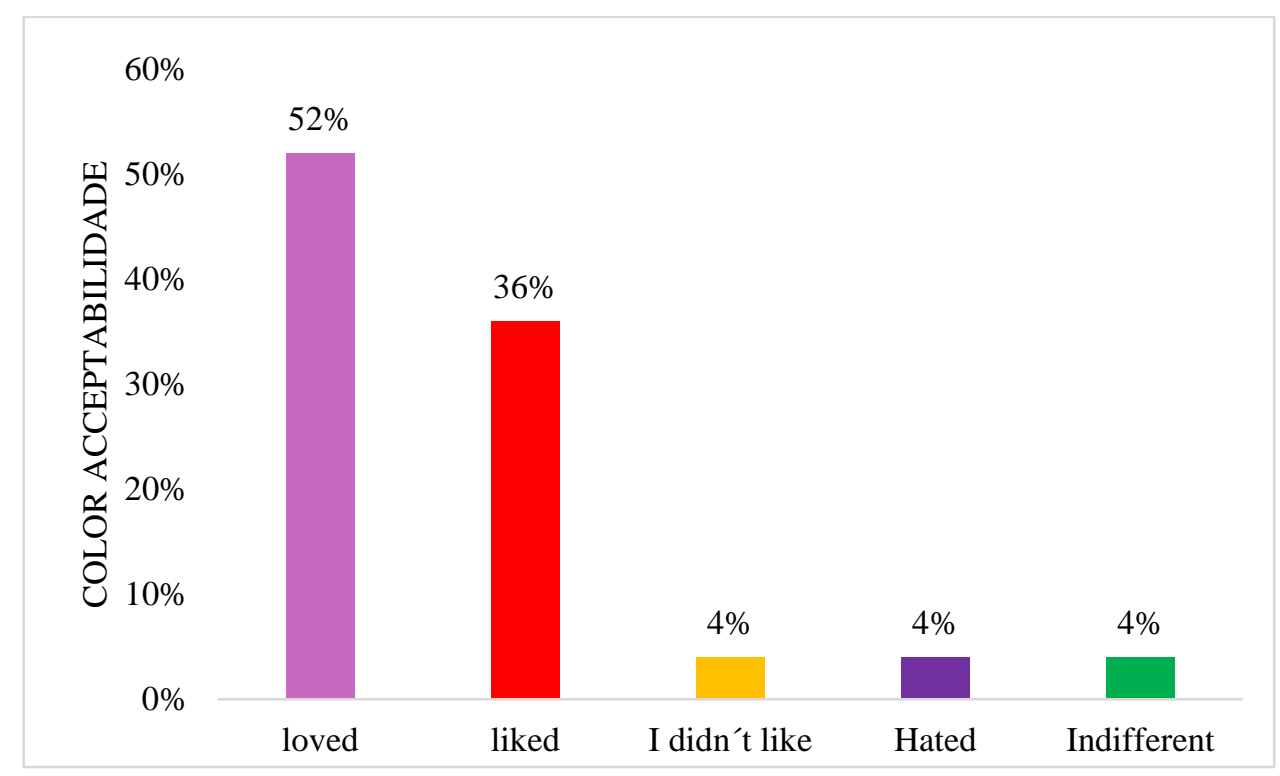

Source: Authors (2021).

The answers obtained regarding the good acceptance of the color of the biscuits was surprising since the green color of the dry leaf of the flour stood out in the biscuit, was different from the traditional colors of homemade and/ or industrialized biscuits.

Regarding the taste, the evaluation of the children proposed to the study a good result. Figure 2 shows that $60 \%$ reported having "loved" the biscuit, $28 \%$ who "liked it", $8 \%$ who "did not like it", only $4 \%$ were indifferent to the taste and there were no reports regarding the "detest" the biscuits.

Figure 2 - Graphic sensory analysis of biscuit of Moringa Oleifera as to the question flavor.

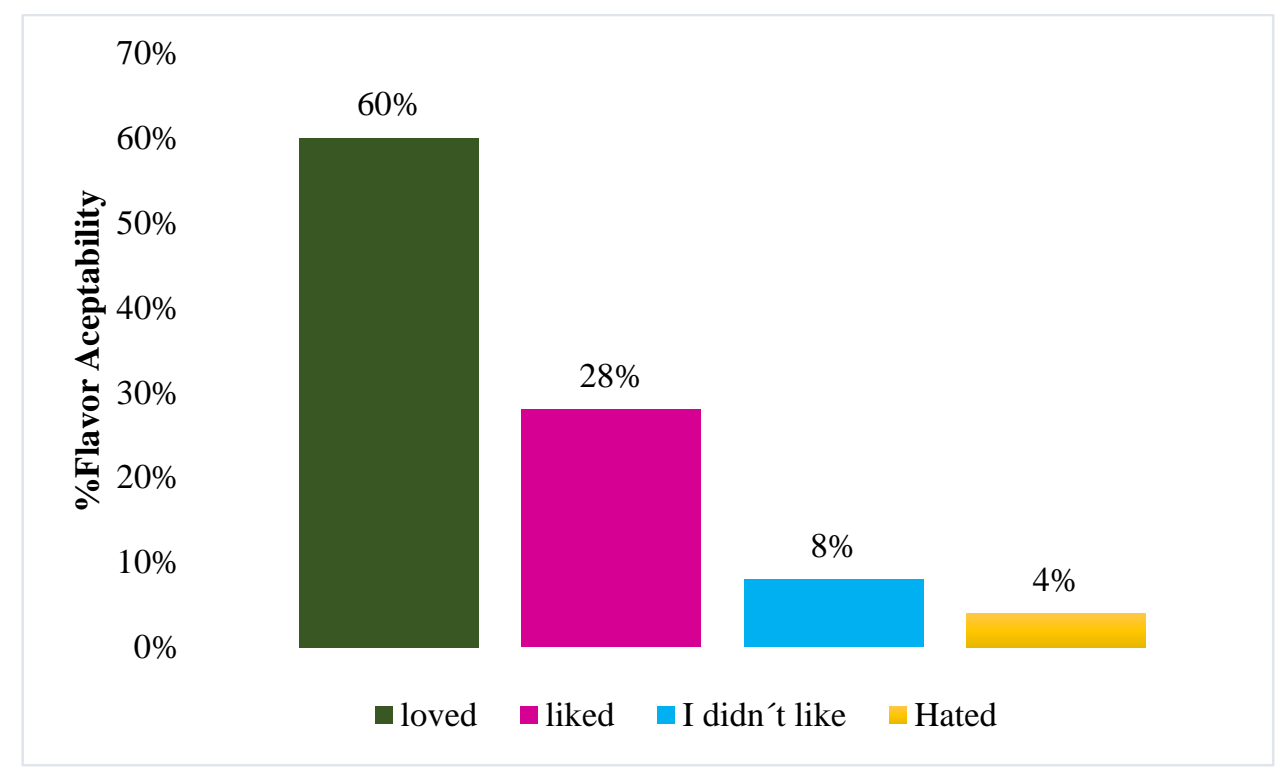

Source: Authors (2021). 
When you talk about taste, it's something very individual, and it changes from person to person. For this reason, when the taste assessment test is carried out, it is not only important that the language of the analyzer is in good condition, but also that it is not having problems with the sea and throat. The taste is also influenced by color and texture (Silva et al., 2020).

The taste is a significant manifestation because it constitutes almost the knockout proof of the food. The flavor receptor organs are located in the tongue, the base and tip of it do not present greater sensitivity. In addition to the tongue, there are also other points of sensitivity of the flavor, located in the gums, hard palate, tonsils, and epiglottis (Lopes et al., 2020).

The texture is a determining factor in the quality of biscuits, responsible for defining the acceptance and sale of these products (Dutcosky, 2011). This attribute is related to hardness, fracturing, and crispness in these bakeries. The textured aspect was also evaluated in the sensory analysis, $68 \%$ of the evaluators reported having "worshipped", that is, they found the texture as soft, $24 \%$ reported that they "liked" and $8 \%$ who "did not like it". By performing different forms of biscuit preparations, until obtaining the final product, it can be seen that the corrector appropriate form of preparation influences the texture of the food, as well as the temperature and preparation time. Carelle and Cândido (2014) described that the preparation of food in dietary technique should ensure: adequate nutritional value of food and pleasant palatability, which guarantees the acceptance of the preparation by the consumer.

Many studies carried out with different types of cookies have shown a strong tendency of industries to promote the enrichment of these foods because they are a low-cost product that can easily be consumed by the less privileged social class (Castro, 2017; Carvalho Neto, 2017; Mensah et al, 2012; Moreira (2016)), reported that the mixture of flour from nonconventional products, together with wheat flour, for example, improves the nutritional quality of biscuits and can even improve their palatability, which makes them more accepted by consumers.

\section{Conclusion}

According to the results obtained, Moringa oleifera flour can be considered a good source of proteins, carbohydrates, fibers, iron, and vitamin $\mathrm{C}$ when compared with other food sources, such as non-conventional vegetables. Thus, it may present as a new supplement alternative in food preparations in the diet of children, adolescents, and adults.

The preparation of the biscuit recipe also demonstrated that it can be an income alternative for communities living from the extractives of Moringa oleifera or those that have in their community the cultivation of the moringa tree in large numbers, as is the case of those living in the region of Guinea Bissau, in west Africa. It is worth mentioning that the values obtained from the iron and vitamin $\mathrm{C}$ contents of the cookies produced can be considered a good food possible for the prevention and treatment of iron deficiency anemia in children of all social levels, because the recipe has a considerably low cost, in addition to good acceptability.

Most of the world's population is unaware of its potential or does not have safety in its consumption, which highlights the need to carry out further studies on its nutritional quality, interventions, disclosures, nutritional guidance regarding its benefits regarding its relevance in health promotion, prevention, and treatment of diseases.

\section{References}

Almeida, M. S. M (2018). Moringa oleifera Lam, seus benefícios medicinais, nutricionais e avaliação de toxicidade. [Dissertação de Mestrado Integrado em Ciências Farmacêuticas, Faculdade de Farmácia, Universidade de Coimbra-Portugal].

Association Of Official Agricultural Chemists - AOAC. (2016). Official methods of analysis of the Association Analytical Chemists. (20a ed.), Gaithersburg: Maryland.

Baptista, A. T. A., Silva, M. O., Bergamasco, R. \& Vieira, A. M. S. (2012). Avaliação físico-química e sensorial de biscoitos tipo cookies elaborados com folha de Moringa oleifera. Boletim do centro de Pesquisa de processamento de Alimentos. 30(1): 65-74.

Brasil (2005). Ministério da Saúde, Agência Nacional de Vigilância Sanitária. Resolução no 269, de 22 de setembro de 2005 . Regulamento técnico sobre a ingestão diária recomendada (IDR) de proteína, vitaminas e minerais. Diário Oficial da União. https://www.gov.br/agricultura/pt-br/assuntos/inspecao/produtos- 
vegetal/legislacao-1/biblioteca-de-normas-vinhos-e-bebidas/resolucao-rdc-no-269-de-22-de-setembro-de-2005.

Brasil (2005). Ministério da Saúde, Agência Nacional de Vigilância Sanitária. Resolução nº 263, de 22 de setembro de 2005 . Regulamento técnico para produtos de cereais, amidos, farinhas e farelos. Diário Oficial da União. em:https://bvsms.saude.gov.br/bvs/saudelegis/anvisa/2005/rdc0263_22_09_2005.html.

Brasil (2014). Ministério da Saúde. Secretaria de Atenção à Saúde. Departamento de Atenção Básica. Guia alimentar para a população brasileira / Ministério da Saúde, Secretaria de Atenção à Saúde, Departamento de Atenção Básica. (2 ed.), Ministério da Saúde.

Câmara, G. B., Oliveira, T. K. B., Macedo, S. C., Leite, D. D. F., Soares, T. C, Lima, A. R. N., Vasconcelos, S. H., Soares, T. C., Barbosa, M. L., \& Trigueiro, L. S. L. (2019). Caracterização físico-química, toxicológica e nutricional das folhas da Moringa oleifera secas e in natura. Research, Society and Development. $8(11): 1-13$.

Carelle, A. C., \& Cândido, C. C. (2014). Técnicas Dietéticas. Editora: Érica.

Carvalho Neto, A. S. F. (2017). Análise de viabilidade econômico-financeira da produção e exportação de óleo de semente e pó de folha de Moringa oleifera. [Dissertação de Mestrado em Ciência, Tecnologia e Inovação - Escola de Ciências e Tecnologia, Universidade Federal do Rio Grande do Norte, Natal].

Castro, R.P. (2017). Desenvolvimento de bioprodutos inovadores derivados da moringa (Moringa oleifera). [Dissertação de Mestrado em Ciência, Tecnologia e Inovação - Escola de Ciências e Tecnologia, Universidade Federal do Rio Grande do Norte, Natal].

Chisté, K. O., Cohen, K. O., Mathias, E. A., \& Ramoa Júnior, A. G. A. (2006). Qualidade da farinha de mandioca do grupo seca. Revista Ciências e Tecnologia de Alimentos. 26(4):861-864.

Dutcosky, S. D. (2011). Análise sensorial de alimentos. (3a ed.), universitária Champagnat.

Estrela, C. (2018). Metodologia Científica: Ciência, Ensino, Pesquisa. Editora Artes Médicas, (3a ed).

Fruet, A. P. B., Stefanello, F. S., Silva, M. S., Kirinus, J. K., Nörnberg, J. L., Teixeira, C., \& Dörr. A. C. (2014). Incorporação de fibra alimentar em produtos cárneos. Revista Eletrônica em Gestão, Educação e Tecnologia Ambiental. 18(Ed. Especial):11-17.

Gasqui, D. L., Marinelli, P. S., Otoboni, A., Tanaka, A, Y., \& Oliveira, A. S. (2015). Caracterização química e nutricional da farinha de moringa (Moringa oleifera Lam.). Revistas Cientificas Eletrônicas. 4(1):01-09.

Gueiros, M. A. F., Marinelli, O. S., Otoboni, A. M. M. B., Tanaka, A. Y., \& Oliveira, A. S. (2019). Caracterização química e nutricional da farinha de moringa (Moringa oleifera Lam.). IV Congresso Internacional das Ciências Agrárias COINTER - PDVAgro. Universidade Federal Rural de Pernambuco, PE, Brasil. https://cointer.institutoidv.org/inscricao/pdvagro/uploadsAnais2020/CARACTERIZA\%C3\%87\%C3\%83O-F\%C3\%8DSICO-QU\%C3\%8DMICA-DA-

FOLHA-MORINGA-(Moringa-oleifera-Lamarck)--EM-P\%C3\%93.pdf.

Helvio, B. (2007). Moringa oleifera, el maná verde del trópico, cultivo, comercialización. 2007.

Instituto Adolfo Luttz. (2008). Normas Analíticas do Instituto Adolfo Lutz. Métodos físico-químicos para análises de alimentos, (4a ed).

Lopes, G. S., Dias, G. S., \& Mondego, J. M. (2020). Estudos aplicados à análise sensorial de alimentos [recurso eletrônico]. Nova Xavantina, MT: Pantanal, 2020. 50p.

Macambira, G. M., Rabello, C. B. V., Navarro, M. I. V., Ludke, M. C. M. M., Silva, J. C. R., Lopes, EC., Nascimento, G. R., Lopes, C. C., Bandeira, J. M., \& Silva, D. A., (2018) Caracterização nutricional das folhas de Moringa oleifera (MOL) para frangos de corte. Arquivo Brasileiro de Medicina Veterinária e Zootecnia. 70(2):570-578.

Mensah, J. K., Emelike, N. J.T., Uwa, F. O., Ebere, C. O., \& Naik, M. R. (2012). Phytochemical, nutritional, and antibacterial properties of dried leaf powder of Moringa oleifera (Lam.)from Edo Central Province, Nigeria. Journal of Natural Products and Plants Resources. 2(1): 107-112.

Modesti, C. F. (2006). Obtenção e caracterização de concentrado proteico de folhas de mandioca submetido a diferentes tratamentos. [Dissertação de Mestrado em Agronomia, área de concentração Agroquímica e Agro bioquímica - Universidade Federal de Lavras, Lavras, MG].

Monteiro, A. R. G. (2005). Introdução à análise sensorial de alimentos. Eduem. p. 24-36.

Moreira, L. N. (2016). Técnica dietética. SESES. p. 240.

Moura, A. S., Souza, A. L. G., Oliveira Júnior, A. M., Lira, M. L., \& Silva, G. L. (2009). Caracterizaçãofísico-química da folha, flor e vagem da Moringa oleifera Lamarck. Documento apresentado em Encontro Nacional de Moringa. Aracaju - Sergipe.

Moyo, B., Masika, P. J., Hugo, A., Muchenje, V., \& Muchenje, V. (2011). Nutritional characterization of Moringa oleifera (Moringa oleifera) leaves. Afr. J. Biotechnol. African Journal of Biotechnology. 10(60):12925-12933.

Organização Mundial de Saúde. (2015). Lucha contra la anemia nutricional, especialmente contra la carência de hierro: Informe ADI/OIEA/OMS. Série de Informes Técnicos, 580. Genebra: OMS, Micronutrientes na lactação.

Pinheiro, D. M., Porto, K. R. A., \& Menezes, M. E. S. (2005). A Química dos Alimentos: carboidratos, lipídeos, proteínas, vitaminas e minerais. EDUFAL Editora da Universidade Federal de Alagoas, Maceió.

Rocha, D. R. C., Pereira, G. A., Vieira. G., Pantoja, L., Santos, A. S., \& Pinto, N. A. V. D. (2008). Macarrão adicionado de ora-pro-nóbis (Pereskia aculeata Miller) desidratado. Brazilian Journal of Food and Nutrition. 19(4):459-465.

Romero, R. C., Corrales, V. H. D., \& Montaño G. T. (2015). Aspectos importantes de Moringa oleifera: una alternativa para tratar la anemia por deficiencia de hierro. Revista de Ciencias Biológicas y de la Salud. (1):1-7. 
Research, Society and Development, v. 11, n. 3, e36811326790, 2022

(CC BY 4.0) | ISSN 2525-3409 | DOI: http://dx.doi.org/10.33448/rsd-v11i3.26790

Santana, M. F. S., Gonçalves, L. M. F., \& Oliveira, C. G. M. (2008). Biscoitos enriquecidos com farinha do mesocarpo de babaçu. In: Congresso brasileiro de ciência e tecnologia dealimentos, 21. Seminário latino americano e do Caribe de ciência e tecnologia de alimentos, 15. SBCTA.

Santos, A. F. R., Pontes, E. D. S., Araújo, M. G. G., Melo, P. C. M. F., Viera, V. B., \& Jerônimo, H. M. A. (2020). Elaboração e caracterização física e físicoquímica de um brownie enriquecido com farinha da folha de Moringa (Moringa oleifera). Research, Society and Development. 9(7):101973927.

Shija, S. J., Mikali, H., \& Islam A. (2009). Efeito da suplementação de folhas de Moringa oleifera em pó na redução da anemia em crianças menores de dois anos no distrito de Kisarawe, na Tanzânia. Food Science Nutrition. 7(8):2584-2594.

Siguemoto. É. S. (2013). Composição nutricional e propriedades funcionais do murici (Byrsomina crassifolia) e moringa (Moringa oleifera). [Dissertação de Mestrado, Nutrição em Saúde Pública, Faculdade de São Paulo, USP].

Silva, J. C., Marques, R. G., Teixeira, B. E. M., \& Ciabotti, S. (2001). Teores de proteínas e fibras das folhas de taioba, ora-pro-nobis, serralha e mostarda coletadas no município de Diamantina. CNPq/UFVJM.

Silva, L. S. V., Souza, A. P. T. G. G., Saunders, C. \& Ramalho, A. (2007). Micronutrients in pregnancy and lactation. Revista Brasileira de Saúde Materno Infantil. 7(3):237-244.

Silva, S. N., Gomes, J. P., \& Matos, J. D. P. (2020). Composição físico-química de sementes de moringa oriundas de dois estados do nordeste brasileiro. Revista de Agroecologia no Semiárido (RAS) - (Sousa - PB). 4(5):63-71.

Tabela brasileira de composição de alimentos (TACO). (2011). (4a ed). NEPA UNICAMP.

Tabela Brasileira de Composição de Alimentos. TBCA. (2020). Universidade de São Paulo (USP). Food Research Center (FoRC). (versão 7.1).

Tavares, J. T. Q., Santos, C. M., De Carvalho, L. A., \& da Silva, C. L. (1999). Determinação volumétrica de ácido ascórbico pelos métodos de Tilmans e Balemtine. Magistra. 7:1-8.

Teixeira, E. M. B. (2012). Caracterização química e nutricional da folha de moringa (Moringa oleifera). [Tese de Doutorado em Alimentos e Nutrição, Universidade Estadual Paulista Júlio de Mesquita Filho].

Teixeira, E., Meinert, E. M., \& Barbetta., P. A. (1987). Análise sensorial de alimentos. UFSC.

Tibola. C. S., De Mori, C., Guarienti, E. M., Lorini, I., Lima, M. I. P. M., \& Miranda, M. Z. (2010). Gestão daqualidade do trigo na pós-colheita. In: Pires J. L. F., Vargas, L., Cunha, G. R. Trigo no Brasil Bases para a produção competitiva e sustentável. Passo Fundo: Embrapa Trigo. 16:391-426. 